\title{
Punishing Status and the Punishment Status Quo: Solitary Confinement in U.S. Immigration Prisons, 2013-2017
}

\author{
Konrad Franco ${ }^{1}$ \\ Caitlin Patler ${ }^{1}$ \\ Keramet Reiter ${ }^{2}$
}

\section{Citation:}

Franco, K., Patler, C., \& Reiter, K. (In Press). Punishing Status and the Punishment Status Quo: Solitary Confinement in U.S. Immigration Prisons, 2013-2017. Punishment \& Society. https://doi.org/10.1177/1462474520967804.

SocArXiv Version: 4.0

Last updated: October 29, 2020

${ }^{1}$ Department of Sociology, University of California, Davis.

${ }^{2}$ Department of Criminology, Law and Society, University of California, Irvine.

Corresponding Author: Konrad Franco (klfranco@ucdavis.edu).

Acknowledgements: This research received generous support from the University of CaliforniaMexico Initiative and the UC Davis Global Migration Center. The authors thank the Transactional Records Access Clearinghouse and Spencer Woodman with The International Consortium of Investigative Journalists for sharing data from FOIA requests. The authors also thank the two anonymous reviewers and editorial team. Ryan Finnigan, Xiaoling Shu, and participants of the UC Davis Department of Sociology Social Control Research Cluster and the UC Davis Global Migration Center provided generous feedback along the way. 


\begin{abstract}
This study provides the first systematic, nationally representative analysis of administrative records of solitary confinement placements in any carceral setting. We examine patterns in who experiences solitary confinement in Immigration and Customs Enforcement (ICE) custody, as well as the stated reason for, and length of, their confinement. We reveal several findings. First, cases involving individuals with mental illnesses are overrepresented, more likely to occur without infraction, and to last longer, compared to cases involving individuals without mental illnesses. Second, solitary confinement cases involving immigrants from Africa and the Caribbean are vastly overrepresented in comparison to the share of these groups in the overall detained population, and African immigrants are more likely to be confined for disciplinary reasons, compared to the average. Finally, placement patterns vary significantly by facility and institution type, with private facilities more likely to solitarily confine people without infraction, compared to public facilities. This study offers a lens through which to more precisely theorize the legal boundary-blurring of crimmigration and the relationship between prison and immigration detention policies, to better understand the practice of solitary confinement across carceral contexts, and to analyze the relationship between national-level policy and on-the-ground implementation.
\end{abstract}

\title{
Keywords
}

solitary confinement, immigration detention, punishment, discretion 


\section{Introduction}

In 2019, U.S. Immigration and Customs Enforcement (ICE) imprisoned over 52,000 people per day, a daily population 22 times greater than in 1973 (Aleaziz, 2019; Patler and Golash-Boza, 2017). ICE subcontracts detention to three to five hundred facilities per year, including local jails holding a mix of ICE detainees and local prisoners or, in the majority of cases, for-profit prison corporations operating standalone facilities (Saadi and Tesema, 2019). Immigration prisons ${ }^{1}$ are physically similar to jails and prisons more generally: imposing steeland-concrete structures, with limited access to outdoor areas and natural light, surrounded by barbed wire fences and armed guards controlling all entrances and exits. These physically comparable facilities are also experienced similarly by detained people (Longazel et al., 2016). Still, there are legal distinctions between imprisonment in the criminal and immigration law contexts that underscore the importance of understanding conditions of confinement. For one, detained immigrants are not serving sentences: immigration detention is legally considered a non-punitive administrative process meant to ensure compliance with deportation proceedings. Detention therefore does not convey the same constitutional protections as in the criminal context, including the right to a trial to determine whether prolonged detention is justified. ${ }^{2}$

\footnotetext{
${ }^{1}$ Immigration detention is most accurately described as imprisonment, and detained people as prisoners. However, because one of the goals of our study is to build on research on prisons and jails, and because the two systems are legally distinct (even if they operate identically), we use "detention" or "immigration prisons" to describe immigration detention and "detained person" to describe individuals held by ICE. This allows the reader to more easily distinguish between the immigration and criminal systems and, ultimately, to observe their problematic similarities. In the future, we urge scholars to move toward using "immigration prisons."

${ }^{2}$ Immigration law requires mandatory detention for asylum seekers awaiting a credible fear interview and non-citizens (even lawful permanent residents) who have criminal records. As of March 2020, 61 percent of detained people had no criminal conviction, and only ten percent had a serious conviction (TRAC, 2020).
} 
Detention can therefore extend indefinitely (Transactional Records Access Clearinghouse (TRAC), 2013). Yet despite the vast and growing use of immigration detention in the United States, information on the conditions of confinement within ICE facilities is extremely limited. One of the least understood practices within detention centers is solitary confinement, leading scholars to describe the practice as a black box within a black box (Patler et al., 2019). To date, the only national-level examinations of federal data consist of in-depth analyses by investigative journalists and advocacy organizations, which describe immigrants locked in windowless cells, alone for 22-23 hours each day, sometimes for weeks or months at a time, and often with long-term negative effects (Schwellenback et al., 2019; Urbina and Rentz, 2013; Woodman et al., 2019). Immigrants held in solitary confinement, "suffered hallucinations, fits of anger, and suicidal impulses. Former [solitarily confined] detainees ... experienced sleeplessness, flashbacks, depression, and memory loss long after release (Woodman et al., 2019)." Only one existing academic study has examined solitary confinement within the immigration detention context (Patler et al. 2019). That study revealed similarly troubling patterns: mentally ill individuals were overrepresented in solitary confinement, the practice was linked to the onset or worsening of mental illness, and privately-operated facilities were more likely to use the practice. However, the analysis included only facilities in California.

The present study provides the first national analysis of patterns and practices of solitary confinement use in immigration detention facilities across the United States. We analyze all documented cases of solitary confinement lasting 14 days or longer between September 2013 and March 2017 ( $\mathrm{n}=5,327)$. Solitary confinement for 14 days triggers universal reporting requirements, pursuant to a 2013 ICE directive requiring facilities to keep records on its use of 
solitary confinement (ICE, 2013). ${ }^{3}$ The 14-day trigger likely reflects international standards; the United Nations argues that solitary confinement in excess of 15 days should be banned, and should never be permitted for individuals with mental illness, because it can amount to cruel, inhuman, or degrading treatment, or even torture, in violation of international human rights standards (UN News, 2011; United Nations, 2016). Documenting and analyzing solitary confinement use in all carceral settings is especially salient, given the potential for serious human rights violations associated with the practice.

Beyond its practical relevance, our study has empirical and theoretical motivations. First, no national dataset exists that can examine all cases of solitary confinement in U.S. criminal prisons; our dataset is therefore the first of its kind in any legal context. We thus provide a window for better understanding the practice of solitary confinement itself. Second, while immigration prison conditions are still largely a black box, research on solitary confinement in the criminal law context has revealed both disproportionate impacts on some groups of vulnerable individuals and administrative discretion as a central determinant of solitary confinement practices (e.g., Reiter, 2012, 2016b; Sakoda and Simes, 2020). Given the vast expansion of crimmigration - the intertwining of the most punitive aspects of criminal and immigration law as a means of racial social control (Barker, 2017; Bosworth, 2017; Stumpf, 2006) - we hypothesize that these patterns likely also exist in the immigration context. We focus on operationalizing variables like mental illness status and region of origin, as well as institutional characteristics like privatization and degree of discretion in imposing solitary confinement, to test our hypotheses about similar use patterns across criminal and immigration

${ }^{3}$ ICE Directive 11065.1 "Review of the Use of Segregation for ICE Detainees," is available at: https://perma.cc/8GHX-VL8V. 
contexts and further theorize the legal boundary-blurring of crimmigration. Finally, our data allow us to examine the theoretical relationship between national-level policy and on-the-ground implementation. At a time of dizzying federal regulatory change, mining institutional data to better understand the contagion, and local-level variability, of hidden and discretionary administrative practices is especially salient.

\section{The Punishment Status Quo: An Epidemic of Solitary Confinement}

The exact conditions that constitute solitary confinement, the labels describing it, and the stated purposes of the practice vary widely across institutions and jurisdictions (Beck, 2015; Cohen, 2014; Kurki and Morris, 2001; Labrecque, 2019; Lovell et al., 2000; Rubin and Reiter, 2018), making the practice difficult to measure and evaluate. Scholars of solitary confinement in the criminal context debate everything from its scale (between 80,000 to 250,000 individuals annually) (Beck, 2015; Lovell and Toch, 2011; Naday et al., 2008), to how harmful it is (Haney, 2018; Morgan et al., 2016), to its purpose (Lovell et al., 2007; Reiter, 2015). Still, as attention to the practice increases, some academic consensus is coalescing.

Scholars agree that solitary confinement, in both the criminal and immigration context, has increased in tandem with mass incarceration (Patler et al. 2019; Reiter 2016a; Rubin and Reiter 2018; Sakoda and Simes 2020; Schwellenback et al. 2019; Woodman et al. 2019). Legal and social science analyses alike demonstrate that solitary confinement, at least in the criminal context, is often imposed arbitrarily, by prison officials in perfunctory administrative hearings (Dolovich, 2012; Reiter, 2016a; Reiter and Coutin, 2017; Resnik, 2020), with disparate use among racial minorities (Pyrooz and Mitchell, 2019; Reiter, 2012, 2016b; Sakoda and Simes, 2020), and those with pre-existing or new physical and mental health problems (Haney, 2018; 
Kaba et al., 2014; Kupers, 2017; Lovell, 2008; Patler et al., 2019; Reiter et al., 2020; Reiter and Blair, 2015; Williams et al., 2019).

Indeed, vulnerable populations, including juveniles, pregnant women, and especially people with mental illness, are likely to be especially susceptible to the negative consequences of restrictive conditions of solitary confinement (American Civil Liberties Union, 2019; Haney, 2018; Kraner et al., 2016; Reiter, 2016a; Reiter et al., 2020). Yet, solitary confinement is often the de facto holding place for prisoners who may be unsafe in the general prison population or those who administrators deem could make other prisoners feel unsafe: transgender people, gang leaders and dropouts, seriously mentally ill individuals, and most recently, those infected with COVID-19 (Pyrooz and Mitchell, 2019; Reiter and Blair, 2018; Unlock the Box, 2020). We assess whether similar patterns emerge in the use of solitary confinement in the immigration detention context.

\section{Punishing Status: Crimmigration and Mass Immigrant Detention}

Just as incarceration increased with more and longer criminal sentences over the past several decades, so too has immigration law enforcement, including deportations and detention (Golash-Boza, 2016; King et al., 2012; Patler and Golash-Boza, 2017). Although immigrants in detention are awaiting decisions on their immigration court proceedings, not serving criminal sentences, they can spend months, if not years in prison-like detention facilities; 85,363 people were jailed for longer than thirty days and 24,897 people for longer than six months in FY 2015 (TRAC, 2013).

"Crimmigration" literature emerged to describe the convergence of immigration and criminal law's harshest elements. Crimmigration scholars argue that exclusion, immobilization, and expulsion are the roles and justifications of both legal systems, ultimately making them co- 
constitutive (Stumpf, 2006, Bosworth, 2017; Bosworth et al., 2018). Further, as Barker has argued, the merging of "penal power and migration control" undermines "basic principles of justice," amplifying indignity, disrespect, and exclusion (2017: 452-3).

A growing body of literature documents the crimmigration convergence and the individual harms and institutionalized inequity it can cause (Beckett and Evans, 2015; Bosworth et al., 2018; Chacon, 2012; Eagly, 2010; García Hernández, 2014; Reiter and Coutin, 2017; Stumpf, 2006). One area of research seeks to document punitive experiences in crimmigration processes and experiences, including in detention facilities. Scholars argue that despite the legal differences between criminal incarceration and immigration detention, the physical and emotional experiences of the systems are parallel (García Hernández, 2017; Longazel et al., 2016; Patler and Branic, 2017; Reiter and Coutin, 2017). Detained people experience "pains of imprisonment" (containment, exploitation, coercion, and legal violence) much as prisoners do, in contexts that are comparably racialized and systemically abusive (Longazel et al., 2016; see also Brouwer, 2020; Crewe, 2011; Kox et al., 2020). Conditions of confinement in immigrant detention facilities are troublingly similar to prisons and jails; e.g., lack of legal access, problems with family visitation, inadequate or inedible food, and subpar or grossly negligent healthcare (Eagly and Shafer, 2015; Golash-Boza, 2015; Longazel et al., 2016; Patler and Branic, 2017; Saadi et al., 2020). Of course, detained immigrants may also experience distinctive types of uncertainty as they await judicial decisions about whether they will be permanently expelled from the land they call or hope to call home (Bosworth, 2014; Brouwer, 2020; Hasselberg, 2016).

Solitary confinement represents one of the most severe and punitive aspects of crimmigration policy. Indeed, the prison literature shows it is both experienced as punitive and 
often imposed by prison officials for functionally punitive purposes, even when labeled as administrative or non-punitive (Haney, 2018; Kupers, 2017; Reiter and Coutin, 2017; Sakoda and Simes, 2020). This punitive and harmful condition of confinement operates similarly in the immigration detention context but is subject to even less regulation than in prisons. By focusing on everyday solitary confinement practices in immigration detention, we examine crimmigration not just as a law making process, but also as a law implementing process-for example, by demonstrating that local-level law enforcement officials can differentially implement this punitive form of social control (van der Woude et al., 2014).

\section{Punitive Variability}

A robust body of punishment and crimmigration scholarship demonstrates how nominally uniform policies are implemented differently across different institutions, varying especially with institutional characteristics, such as whether a given facility is privatized (Lundahl et al., 2009; Patler et al., 2019; Spivak and Sharp, 2008) and where it is located (Campbell and Schoenfeld, 2013; Gilmore, 2007; Lynch, 2010; Ryo and Peacock, 2018; Schept, 2013; Schoenfeld, 2010). Administrative discretion (e.g., Reiter, 2016b), local politics (e.g., Barker, 2009; Provine et al., 2016), and profit motives (e.g., Lundahl et al., 2009) can also influence outcomes, from how vigorously a jurisdiction polices immigrants (Provine et al., 2016) to the scale and harshness of conditions of incarceration (Barker, 2009; Lynch, 2010; Reiter, 2016b). These variations in practice across institutions and jurisdictions contribute to a broader theoretical body of work challenging the presumption of centralized federal policy in both the criminal (e.g., Campbell and Schoenfeld, 2013; Lynch, 2010) and immigration (e.g., Patler et al., 2019; Ryo and Peacock, 2018) contexts. 
Patterns in solitary confinement use across different immigration detention facilities and jurisdictions, all of which are governed by uniform federal standards, allow for an evaluation of how consistently these uniform standards are applied in practice. To the extent differences in facility characteristics - like size, geographic location, or privatization - explain variation in solitary confinement use, we contribute to this body of theory challenging the presumption of centralized federal punishment policy or practice.

\section{Data and Method}

We analyze three administrative datasets from the Department of Homeland Security (DHS), gathered via Freedom of Information Act (FOIA) requests. The first dataset, acquired by the International Consortium of Investigative Journalists (ICIJ), contains 5,237 cases of solitary confinement placements from September 4, 2013 to March 4, 2017, covering cases across 102 facilities under the jurisdiction of 24 ICE Field Office Areas of Responsibility (AORs). The second dataset, acquired by TRAC, contains individual-level data on all 355,678 people detained by ICE during FY 2015 (October 1, 2014 to September 30, 2015), the only year for which such data exist for public use. This allows us to compare solitary confinement cases to overall ICE populations. The third dataset, also acquired by TRAC, contains information on all ICE detention facilities from 2009 to 2018, allowing us to control for facility-level characteristics that may impact solitary confinement use.

\section{Measures and Analytical Approach}

Informed by research on solitary confinement in prison and immigration contexts, we begin by testing whether the use of solitary confinement in immigration prisons disproportionately impacts some groups and whether it varies significantly across institution types or facilities. We then model two dependent variables: a continuous variable for length of 
solitary confinement stay (calculated by subtracting the release date from placement date) and a binary variable to capture the reason for placement into solitary confinement $(1=$ solitary confinement without infraction, $0=$ solitary confinement with infraction). ${ }^{4}$ We examine variations in both dependent variables across individual characteristics, facility type (public or private), and AOR.

To account for the potential lack of independence between cases and facilities, we use multi-level mixed effect logistic regression for placement reason and multi-level mixed effect negative binomial (NB) regression for confinement length. We allow each facility to have their own intercept and we include AOR fixed effects. Our two-level mixed effect models include two categories of independent variables: case-level (level-1) characteristics and facility-level (level2) characteristics. Case-level measures include binary variables for gender $(1=$ male, $0=$ female, as defined by ICE), mental illness ( $1=$ yes, $0=$ no), and whether the individual had an attorney of record $(1=$ yes, $0=$ no), as well as categorical, effect-coded variables for region of origin $(1=$ Africa, 2 = Asia, 3 = Caribbean, $4=$ Central America, $5=$ Europe, $6=$ Mexico, $7=$ Middle East,

${ }^{4}$ Our binary categorization of solitary confinement placement reasons replicates analyses from the prison literature (Association of State Correctional Administrators (ASCA) and Liman Center, 2016; Beck, 2015; Reiter, 2016a), which suggest that placement reason, and especially placement without infraction, is a source of significant administrative discretion and driver of solitary confinement patterns of use (Reiter 2012; 2016a). The original dataset contained a 24category "placement reason" variable that details ICE's primary stated reason for the use of solitary confinement in each case (see Appendix 1). Solitary confinement with an infraction ("disciplinary segregation" [ICE, 2013: page 2]), was the most frequently reported rationale. However, ICE also uses solitary confinement to manage individuals who have not committed a disciplinary infraction, including in cases where an individual is deemed to constitute a facility security threat, needs specialized medical attention, seeks or needs protective custody, has a mental illness, participates in a hunger strike, or is on suicide watch ("administrative segregation" [ICE, 2013: page 2]). We group these placement reasons into the category of solitary confinement without infraction (Appendix 1). 
$8=$ North America, $9=$ Oceania, $10=$ South America) ${ }^{5}$ Facility-level measures include a binary variable for whether a facility is privately operated $(1=$ private, $0=$ public $)$, a continuous measure of facility population size (calculated by averaging the Average Daily Population (ADP) across FY 15 to FY 18), and a continuous measure of the percent of the population ICE labels as "criminal" for each facility (calculated by averaging the "criminal" ADP from FY 15 to FY 18, respectively). ${ }^{6}$

Although this is the first nationally comprehensive analysis of solitary confinement, the data have limitations. First, the data pertain to cases of solitary confinement; ICE redacted all personally identifying information including individuals' names, "alien numbers" (a unique identifier given to each noncitizen), and date of birth. Therefore, some individuals could account for multiple cases of solitary confinement, but the data do not allow us to determine the extent of this possibility. Additionally, although the ICE Directive indicates that a detained person's age, ${ }^{7}$ physical disability, sexual orientation, gender identity, religion or "special vulnerability" cannot a priori determine confinement placement, ICE did not provide these variables, so we cannot evaluate their impact on solitary confinement placement decisions. We also do not have data on the usage of solitary confinement before the ICE Directive was issued; we therefore cannot assess change in the frequency or rate of solitary confinement usage before and after the

${ }^{5}$ This categorization follows that of the United States Office of Immigration Statistics; available at: https://perma.cc/R5SH-ZEK8.

${ }^{6}$ ICE classifies National Crime Information Center (NCIC) offense codes into three seriousness levels. The most serious (level 1) covers "aggravated felonies," level 2 offenses cover other felonies, while level 3 offenses are misdemeanors. In these records, the criminal ADP is the average number of individuals with either a level 1,2, or 3 offense in custody on any given day.

${ }^{7}$ There have been allegations of solitary confinement use among children in the custody of immigration authorities (Associated Press, 2018). 
Directive. ${ }^{8}$ Finally, we observe missingness (ranging from 1.80 to 16.28 percent) on three demographic variables; because ICE did not provide an explanation of missingness in its data, we do not know whether the data are missing at random or missing in a systematically biased fashion. The models we present rely on listwise deletion; sensitivity checks using multiple imputation by chained equations find similar results.

\section{Descriptive Disproportionalities in Solitary Confinement Use}

Table 1 describes the demographic characteristics of detained immigrants subjected to solitary confinement, compared to the overall population of detained immigrants. Immigrants with certain characteristics are overrepresented in solitary confinement cases. For example, 95.63 percent of solitary confinement placements involve a male, but only 79.42 percent of all detained people in the general population are male. Moreover, 20.7 percent of solitary confinement placements involve individuals with a mental illness, compared to an estimated 15 percent of all detained people who have a mental illness (Mehta, 2010). ${ }^{9}$

We also find vast disparities by region of origin. While 24.74 percent of solitary confinement cases involve individuals from Africa or the Caribbean, people from these regions collectively represent only 3.64 percent of all detained people. In other words, African and Caribbean immigrants are overrepresented by a factor of 6.8 in solitary confinement cases when compared to the larger overall detained population.

${ }^{8}$ The frequency of solitary confinement usage increased slightly each FY after the 2013 ICE Directive made data available: there were 1,380 placements in FY 2014, 1,488 in FY 2015, and 1,702 in FY 2016.

${ }^{9}$ The rate of undiagnosed mental illness is unknown in immigration detention centers, prisons, and jails since many of these facilities lack appropriate mental health screening assessments upon booking. 
Length of solitary confinement placement varied widely, across both individual characteristics and placement reason; Figure 1 shows an overall mean of 43 days and a median of 27 days. However, 171 cases ( 3 percent) lasted more than 6 months, including 22 cases lasting over a year and one lasting over two years. These 23 longest-lasting cases had distinctive characteristics: 60 percent of these cases involved individuals with a mental illness; 80 percent were "administrative," with no underlying disciplinary infraction; and 90 percent were in privately-operated facilities.

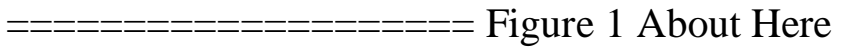

Solitary confinement with an infraction was ICE's most common placement justification: 53 percent of all cases followed an infraction; 47 percent were initiated without an infraction. However, Figure 2 reveals that ICE's stated placement reasons varied widely across detention facilities; ICE facilities seemingly interpret and apply the same regulations differently.

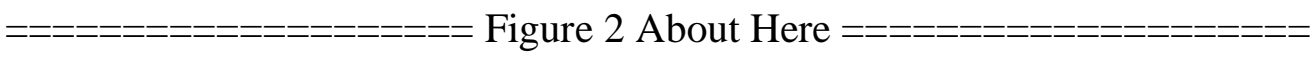

Solitary confinement practices also differ across institution type and size. Some facilities have no reported cases of solitary confinement at all. However, facilities where solitary confinement was used at least once are larger, in terms of their ADP, than the average facility (799 people detained per day vs. 317; Table 1). In addition, facilities that use solitary 
confinement also have a higher share of their population characterized by ICE as "criminal," compared to the average facility (60.69 percent of the facility population vs. 44.62 percent).

\section{Analytical Disproportionalities in Solitary Confinement Use}

Our multilevel regression models reveal that variations in placement reason and length are significantly related to case-and facility-level characteristics and AOR. In Table 2, we display results from two nested mixed effect logit regression models predicting placement reason (with a disciplinary infraction vs. without). The first model controls for demographic and facility variables; the second adds an interaction term between the binary mental illness and private facility variables. In Figure 3, we visualize these regression results by plotting the average marginal effects (AMEs) of the independent variables on the predicted probability of solitary confinement placement without a disciplinary infraction. In Table 3, we show results from two nested mixed effect negative binomial regression models predicting the length of solitary confinement stay. The first model controls for placement reason along with demographic and facility variables; the second adds an interaction term between the binary placement reason and private facility variables. In Figure 4, we plot the average marginal effect (AMEs) of predictors on the predicted number of days spent in solitary confinement. All models control for gender, attorney representation, physical health, mental illness, facility operator type, facility size (average daily population), and average "criminal" ADP. All models also control for AOR and allow for each facility to have their own intercept.

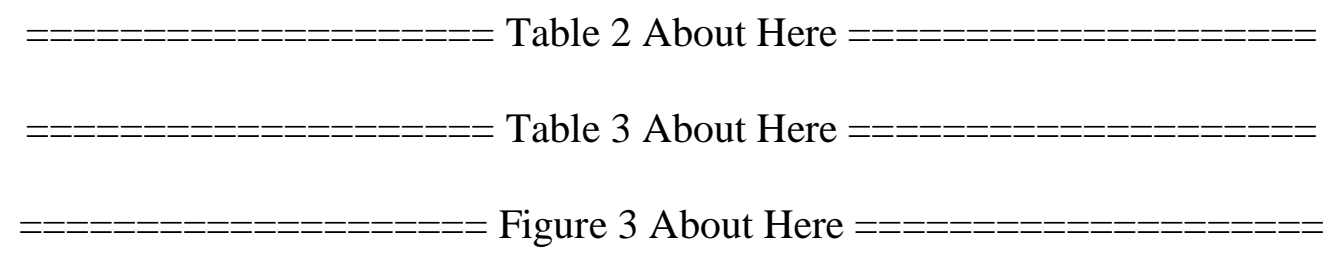


We organize our interpretation of these models around key theoretically- and policy-relevant predictor variables.

\section{Mental Illness}

ICE is more likely to justify solitary confinement cases involving individuals with mental illness as confinement without disciplinary infraction, compared to individuals without mental illness (predicted probability of confinement without infraction is 63 vs. 43 percent). In addition, cases involving individuals with a mental illness last approximately 15 days longer than cases involving individuals without mental illness (56 vs. 41 days).

The placement of individuals with a mental illness in solitary confinement without infraction and for longer periods of time could suggest that solitary confinement is used in times of "medical crises." However, cases ICE defines as involving individuals with a "serious medical issue" last about 18 days less, on average, than cases involving individuals without a serious medical issue. These results strongly suggest that solitary confinement is, rather, an ongoing strategy for managing but not treating mental illness, amplifying prior research focused on immigration detention in California (Patler et al., 2019), and in prisons more generally (Reiter and Blair 2015).

\section{Region of Origin}

Region of origin is significantly correlated with both placement reason and length. ICE is more likely to justify solitary confinement cases involving people from Africa as due to an infraction (i.e. for disciplinary reasons): the predicted probability of solitary confinement without infraction is 33 percent for individuals from Africa, compared to 40 percent for the entire 
sample. Importantly, no individual African country statistically drives this finding, suggesting the possibility of racialized differential treatment. In terms of solitary confinement length, cases involving immigrants from the Middle East last approximately 5 days longer, compared to the grand mean. Cases involving individuals from Mexico last about 2.5 days less, compared to the grand mean. This may be because there are fewer legal options to prevent deportation from Mexico.

\section{Private and Public Facilities}

Facility type is significantly correlated with solitary confinement placement reason and length of confinement. Privately operated facilities are significantly more likely to place individuals in solitary confinement without an infraction (predicted probability of 53 percent), compared to publicly run detention facilities like local jails (predicted probability of 35 percent). Although we find no statistically significant average differences in the predicted length of solitary confinement between private and public facilities, we do find a significant interaction between the facility type and placement reason. As demonstrated in Model 2 of Table 3, cases involving people who are solitarily confined without infraction last an average of 4 days longer if they take place in a private facility, compared to a public facility. This exaggerates an already significant difference between the average length of solitary confinement for cases with and without infraction (30 versus 60 days, respectively).

\section{Detention Facilities and ICE Field Office Areas of Responsibility (AORs)}

Placement reasons and lengths of stay also vary at the facility- and AOR-level (see Appendix 2), suggesting that solitary confinement, though federally regulated, is interpreted differently by different field offices. Although scholars have documented similar variation in solitary confinement across U.S. state prison systems (Association of State Correctional 
Administrators (ASCA) and Liman Center, 2016), each state jurisdiction has distinct rules governing solitary confinement placements. That is not the case with ICE AORs, which are all governed by identical federal regulations, and therefore should not exhibit different practices. While it is beyond the scope of our data to explain the observed variation across AORs, literature from the prison context suggests the possibility that economic (e.g., El Sayed et al., 2020) and political (e.g., Campbell, 2011) factors could contribute to differences across AORs.

\section{Discussion}

Solitary confinement signifies deprivations of human contact, sensory stimulation, and freedom of movement, which increase the risks of severe mental and physical deterioration. For these reasons, the United Nations has declared that more than 15 days in such conditions can constitute torture, in violation of international law (UN News, 2011). Our unique national data set, encompassing the known universe of solitary confinement placements in immigration detention centers between 2013 and 2017, allows us to quantify the scale and analyze the disparate impact of these solitary confinement experiences. We provide the first systematic, national-level analysis of administrative records of solitary confinement placements—not only in immigration detention, but in any carceral setting. Moreover, multivariable analyses of nationallevel administrative data have been missing until now. Our analyses allow us to more precisely theorize the integration not just of criminal and immigration law ("crimmigration"), but also the integration of prison and detention policies governing conditions of confinement and day-to-day treatment. By presenting analyses from the immigration detention context, we can compare our findings with what is already known about solitary confinement use in prisons and jails. Further, we can theorize how these practices might be legally, administratively, and practically related, working together to exclude individuals from civil rights and social benefits. 
We find that solitary confinement use in U.S. immigration detention facilities replicates many of the patterns of solitary confinement use in U.S. prisons. First, solitary confinement in immigration detention punishes status, not only in the general sense of affecting people who have the status of immigrant, but in the more individualized sense of disproportionately affecting people with certain additional status characteristics. Immigrants from Africa and the Caribbean-likely to be racialized minorities - are overrepresented in solitary confinement cases by 680 percent, compared to their share of the detained population. Further, immigrants from Africa are much more likely to experience solitary confinement for disciplinary reasons than the average detained person. This reflects patterns of disproportionate solitary confinement of racial minorities for disciplinary reasons in the prison literature (ASCA and Liman Center, 2016; Reiter, 2012; Schlanger, 2013; Tasca and Turanovic, 2018). Inasmuch as region of origin may be a proxy for race, our findings provide additional evidence that race and systems of punishment are mutually constituted (Cleve and Mayes, 2015), with overly punitive outcomes for Black immigrants.

Detained immigrants who are mentally ill are more likely to be placed in solitary confinement for longer periods than people without mental illness (see also Patler et al., 2019), again reflecting patterns documented in the prison context (Clark 2018; American Civil Liberties Union 2019; Kaba et al. 2014; Reiter et al. 2020; Reiter and Blair 2015). This is particularly troubling since solitary confinement is known to both initiate and exacerbate serious mental illness (Haney, 2018; Reiter and Blair, 2015; UN News, 2011).

Solitary confinement practices also vary across detention institutions and jurisdictions, just as they vary across prison institutions and jurisdictions (Beck, 2015; Cohen, 2014; Kurki and Morris, 2001; Labrecque, 2019; Lovell et al., 2000; Rubin and Reiter, 2018). In particular, 
privately-operated detention facilities are more likely to use solitary confinement for administrative, non-disciplinary reasons, compared to public facilities (e.g., local jails). This suggests that private facilities interpret the same federal policies differently from public facilities, segregating detained people for more vague and variable reasons. Such rogue patterns of behavior by for-profit detention contractors have motivated ongoing litigation and legislative efforts to ensure compliance with basic contractual federal standards, such as California Assembly Bill 3228. ${ }^{10}$

Another central theme of our findings is that administrative discretion governs who is placed in solitary confinement in immigration detention, why, and for how long - just as in the prison context (Dolovich, 2012; Reiter, 2016a; Shapiro, 2019). We find that placement decisions are, at best, inconsistent, and, at worst, arbitrary and, likely, dangerous. In the prison context, scholars have argued that solitary confinement is a magnifying lens for understanding the problems of incarceration more broadly: from the challenges of handling mentally ill prisoners to the broad discretion correctional staff wield over the day-to-day lives of prisoners (Reiter, 2016b; Resnik, 2020). Similarly, solitary confinement in immigration detention is a magnifying lens for understanding both which populations are most vulnerable to detention and how much power ICE officials wield over their lives, a haunting example of crimmigration law in action (van der Woude et al., 2014). The patterns we document strongly suggest that solitary confinement use has been thoroughly integrated into the administrative detention setting of ICE, becoming part of the broader punishment status quo documented in the prison context (Beck, 2015; Cohen, 2014; Kurki and Morris, 2001; Labrecque, 2019; Lovell et al., 2000; Rubin and Reiter, 2018).

${ }^{10}$ See: https://perma.cc/5S7V-JCM5 
Our study represents a crucial step towards better understanding the use of solitary confinement in immigrant detention and in carceral settings, but this topic demands more scholarly attention. More work must address (a) the experiences of marginalized groups (including Black migrants, people with mental illnesses, people who speak languages other than English and Spanish, and LGBT migrants) in solitary confinement, (b) the role of detention facility personnel in interpreting regulations and imposing solitary confinement, and (c) the interrelated health and legal consequences of being solitarily confined in immigration detention.

\section{Conclusion}

In light of both the growing use of solitary confinement in the United States and increasing documentation of its negative health consequences, scholars increasingly call for a public health perspective on this deep end of mass incarceration (Ahalt et al., 2019, 2020; Ahalt and Williams, 2016; Reiter et al., 2020). Such a perspective theorizes the experience of incarceration in extreme conditions as a disease requiring systemic mitigation and treatment, rather than punishment at the individual level, before it spreads like a contagion. To extend the health analogy, our data suggest that solitary confinement is institutionally contagious as wellspreading from the punitive setting of prisons to the administrative setting of immigration detention. The "contagion" analogy is even more pressing and poignant in 2020, with the world facing a global pandemic and imprisoned people across the U.S. facing solitary confinement in an effort to curb the spread of COVID-19 (Cloud et al., 2020), with sometimes deadly consequences (Plevin, 2020).

While a major national and international movement is curbing both the frequency and duration of solitary confinement placements in prisons (at least prior to the COVID-19 pandemic) (ASCA and Liman Center, 2016; Reiter and Blair, 2018), our data suggest that no 
such curbs exist on solitary confinement use in immigration detention. Although the September 2013 ICE directive aimed to encourage "careful consideration of alternatives" to solitary confinement placement and to protect people with "special vulnerabilit[ies]" (ICE, 2013), we find that solitary confinement use is frequent, and vulnerable populations are at more risk of solitary confinement placements than non-vulnerable populations. Moreover, in December of 2019, ICE revised the National Detention Standards that regulate conditions of confinement in immigration detention. The new provisions remove procedural protections preceding solitary confinement placement and permit the use of administrative solitary confinement for a broader range of reasons (Cho, 2020). Given the many disparate impacts of solitary confinement on specific vulnerable groups, and its inconsistent, discretionary application across facilities and regions, the 2019 Standards revision are likely to exacerbate the inequities and inconsistencies we document, even absent the new implications of a pandemic. These inconsistencies and inequities, in turn, run the risk of violating established international human rights protections.

\section{References}

Ahalt C and Williams B (2016) Reforming Solitary-Confinement Policy - Heeding a Presidential Call to Action. New England Journal of Medicine 374(18): 1704-1706.

Ahalt C, Peters C, Steward H, et al. (2019) Transforming Prison Culture to Improve Correctional Staff Wellness and Outcomes for Adults in Custody 'The Oregon Way': A Partnership Between the Oregon Department of Corrections and the University of California's Correctional Culture Change Program. Advancing Corrections Journal 10(8): 130-142.

Ahalt C, Haney C, Ekhaugen K, et al. (2020) Role of a US-Norway Exchange in Placing Health and Well-Being at the Center of US Prison Reform. American Journal of Public Health 110(S1): S27-S29.

Aleaziz H (2019) More Than 52,000 People Are Now Being Detained By ICE, An Apparent AllTime High. BuzzFeed News, 20 May. Available at: https://perma.cc/VWS6-W429. 
American Civil Liberties Union (2019) Still Worse Than Second-Class: Solitary Confinement of Women in the United States.

ASCA and Liman Center (2016) Aiming to Reduce Time-In-Cell: Reports from Correctional Systems on the Numbers of Prisoners in Restricted Housing and on the Potential of Policy Changes to Bring About Reforms. Available at: https://perma.cc/5KD6-4AZJ.

Associated Press (2018) Young immigrants held for years in Virginia detention center claim horrific abuse. NBC News, 21 June. Available at: https://perma.cc/8TG5-BEES.

Barker V (2009) The Politics of Imprisonment: How the Democratic Process Shapes the Way America Punishes Offenders. Oxford, United Kingdom: Oxford University Press.

Barker V (2017) Penal power at the border: Realigning state and nation. Theoretical Criminology 21(4): 441-457.

Beck AJ (2015) Use of Restrictive Housing in U.S. Prisons and Jails, 2011-12. NCJ 249209. Washington, DC: Bureau of Justice Statistics. Available at: https://perma.cc/3FWU$5 \mathrm{KXU}$.

Beckett K and Evans H (2015) Crimmigration at the Local Level: Criminal Justice Processes in the Shadow of Deportation. Law \& Society Review 49(1): 241-277.

Bosworth M (2014) Inside Immigration Detention. First edition. Oxford, United Kingdom: Oxford University Press.

Bosworth M (2017) Immigration Detention, Punishment and the Transformation of Justice: Social \& Legal Studies 28(1): 81-99.

Bosworth M, Franko K and Pickering S (2018) Punishment, globalization and migration control: 'Get them the hell out of here'. Punishment \& Society 20(1): 34-53.

Brouwer J (2020) Bordered penality in the Netherlands: The experiences of foreign national prisoners and prison officers in a crimmigration prison. Punishment \& Society.

Campbell MC (2011) Politics, Prisons, and Law Enforcement: An Examination of the Emergence of "Law and Order" Politics in Texas. Law \& Society Review 45(3): 631-665.

Campbell MC and Schoenfeld H (2013) The Transformation of America's Penal Order: A Historicized Political Sociology of Punishment. American Journal of Sociology 118(5): 1375-1423.

Chacon JM (2012) Overcriminalizing Immigration Symposium on Overcriminalization. Journal of Criminal Law and Criminology 102(3): 613-652.

Cho E (2020) The Trump Administration Weakens Standards for ICE Detention Facilities. ACLU News and Commentary, 14 January. Available at: https://perma.cc/W7NB-DV9T. 
Clark K (2018) The Effect of Mental Illness on Segregation Following Institutional Misconduct. Criminal Justice and Behavior 45(9): 1363-1382.

Cleve NGV and Mayes L (2015) Criminal Justice Through "Colorblind" Lenses: A Call to Examine the Mutual Constitution of Race and Criminal Justice. Law \& Social Inquiry 40(2): 406-432.

Cloud D, Augustine D, Ahalt C, et al. (2020) The Ethical Use of Medical Isolation - Not Solitary Confinement - to Reduce COVID-19 Transmission in Correctional Settings. 9 April.

Amend. Available at: https://perma.cc/67ZD-MR6C.

Cohen F (2014) Long-Term Penal Isolation: A Problem Solving Symposium. Correctional Law Reporter 26(1): 1.

Crewe B (2011) Depth, weight, tightness: Revisiting the pains of imprisonment. Punishment \& Society 13(5): 509-529.

Dolovich S (2012) Forms of Deference in Prison Law. Federal Sentencing Reporter 24(4): 245259.

Eagly IV (2010) Prosecuting Immigration. Northwestern University Law Review 104(4): 12811360.

Eagly IV and Shafer S (2015) A National Study of Access to Counsel in Immigration Court. University of Pennsylvania Law Review 164(1): 91.

García Hernández CC (2014) Immigration Detention as Punishment. Immigration and Nationality Law Review 35: 385-454.

Gilmore RW (2007) Golden Gulag: Prisons, Surplus, Crisis, and Opposition in Globalizing California. American Crossroads 21. Berkeley, CA: University of California Press.

Golash-Boza T (2015) Deported: Immigrant Policing, Disposable Labor, and Global Capitalism. New York, NY: New York University Press.

Golash-Boza T (2016) The Parallels between Mass Incarceration and Mass Deportation: An Intersectional Analysis of State Repression. Journal of World-Systems Research 22(2): 484-509.

Haney C (2018) The Psychological Effects of Solitary Confinement: A Systematic Critique. Crime and Justice 47(1): 365-416.

Hasselberg I (2016) Enduring Uncertainty: Deportation, Punishment and Everyday Life. New York, NY: Berghahn Books.

Kaba F, Lewis A, Glowa-Kollisch S, et al. (2014) Solitary Confinement and Risk of Self-Harm Among Jail Inmates. American Journal of Public Health 104(3): 442-447. 
King RD, Massoglia M and Uggen C (2012) Employment and Exile: U.S. Criminal Deportations, 1908-2005. American Journal of Sociology 117(6): 1786-1825.

Kox M, Boone M and Staring R (2020) The pains of being unauthorized in the Netherlands: Punishment \& Society.

Kraner N, Barrowclough N, Weiss C, et al. (2016) 51 - Jurisdiction Survey of Juvenile Solitary Confinement Rules in Juvenile Justice Systems. Lowenstein Center for Public Interest.

Kupers TA (2017) Solitary: The inside Story of Supermax Isolation and How We Can Abolish It. Oakland, CA: University of California Press.

Kurki L and Morris N (2001) The Purposes, Practices, and Problems of Supermax Prisons. Crime and Justice 28: 385-424.

Labrecque RM (2019) Assessing the Impact of Time Spent in Restrictive Housing Confinement on Subsequent Measures of Institutional Adjustment Among Men in Prison. Criminal Justice and Behavior 46(10): 1445-1455.

Longazel J, Berman J and Fleury-Steiner B (2016) The Pains of Immigrant Imprisonment. Sociology Compass 10(11): 989-998.

Lovell D (2008) Patterns of Disturbed Behavior in a Supermax Population. Criminal Justice and Behavior 35(8): 985-1004.

Lovell D and Toch H (2011) Some Observations About the Colorado Segregation Study. Correctional Mental Health Report 13(1): 3-6.

Lovell D, Cloyes K, Allen D, et al. (2000) Who Lives in Super-Maximum Custody - A Washington State Study. Federal Probation 64(2): 33-38.

Lovell D, Johnson LC and Cain KC (2007) Recidivism of Supermax Prisoners in Washington State. Crime \& Delinquency 53(4): 633-656.

Lundahl BW, Kunz C, Brownell C, et al. (2009) Prison Privatization: A Meta-analysis of Cost and Quality of Confinement Indicators. Research on Social Work Practice 19(4): 383394.

Lynch MP (2010) Sunbelt Justice: Arizona and the Transformation of American Punishment. Critical perspectives on crime and law. Stanford, CA: Stanford Law Books.

Mehta S (2010) Deportation by Default: Mental Disability, Unfair Hearings, and Indefinite Detention in the US Immigration System. New York, NY: American Civil Liberties Union.

Morgan RD, Gendreau P, Smith P, et al. (2016) Quantitative syntheses of the effects of administrative segregation on inmates' well-being. Psychology, Public Policy, and Law 22(4): 439-461. 
Naday A, Freilich JD and Mellow J (2008) The Elusive Data on Supermax Confinement. The Prison Journal 88(1): 69-93.

Patler C and Branic N (2017) Patterns of Family Visitation During Immigration Detention. RSF: The Russell Sage Foundation Journal of the Social Sciences 3(4): 18-36.

Patler C and Golash-Boza TM (2017) The Fiscal and Human Costs of Immigrant Detention and Deportation in the United States. Sociology Compass 11(11): 1-9.

Patler C, Sacha JO and Branic N (2019) The Black Box Within a Black Box: Solitary Confinement Practices in a Subset of U.S. Immigrant Detention Facilities. Journal of Population Research 35(4): 435-465.

Plevin R (2020) 'This death was preventable': Family asks state to probe 74-year-old's suicide in ICE detention. Desert Sun, 7 August. Available at: https://perma.cc/UJ94-AA2N.

Provine DM, Varsanyi M, Lewis PG, et al. (2016) Policing Immigrants: Local Law Enforcement on the Front Lines. Chicago, IL: The University of Chicago Press.

Pyrooz DC and Mitchell MM (2019) The Use of Restrictive Housing on Gang and Non-Gang Affiliated Inmates in U.S. Prisons: Findings from a National Survey of Correctional Agencies. Justice Quarterly: 1-26.

Reiter K (2012) Parole, Snitch, or Die: California's Supermax Prisons and Prisoners, 1997-2007. Punishment \& Society 14(5): 530-563.

Reiter K (2015) Supermax Administration and the Eighth Amendment: Discretion, Deference, and Double-Bunking, 1986-2010. University of California Irvine Law Review 5(1): 530563.

Reiter K (2016a) 23/7: Pelican Bay Prison and the Rise of Long-Term Solitary Confinement. New Haven, CT: Yale University Press.

Reiter K (2016b) Reclaiming the Power to Punish: Legislating and Administrating the California Supermax, 1982-1989. Law \& Society Review 50(2): 484-518.

Reiter K and Blair T (2015) Punishing Mental Illness: Trans-institutionalization and Solitary Confinement in the United States. In: Reiter K and Koenig A (eds) Extreme Punishment. London, England: Palgrave Macmillan UK, pp. 177-196.

Reiter K and Blair T (2018) Superlative Subjects, Institutional Futility, and the Limits of Punishment. Berkeley Journal of Criminal Law 23(3): 162.

Reiter K and Coutin SB (2017) Crossing Borders and Criminalizing Identity: The Disintegrated Subjects of Administrative Sanctions. Law \& Society Review 51(3): 567-601. 
Reiter K, Ventura J, Lovell D, et al. (2020) Psychological Distress in Solitary Confinement: Symptoms, Severity, and Prevalence in the United States, 2017-2018. American Journal of Public Health 110(S1): S56-S62.

Resnik J (2020) Not Isolating Isolation. In: Lobel J and Smith P (eds) Solitary Confinement: Effects, Practices, and Pathways Toward Reform. New York, NY: Oxford University Press, pp. 89-116.

Rubin AT and Reiter K (2018) Continuity in the Face of Penal Innovation: Revisiting the History of American Solitary Confinement. Law \& Social Inquiry 43(4): 1604-1632.

Ryo E and Peacock I (2018) A National Study of Immigration Detention in the United States. Southern California Law Review 92(1): 1-68.

Saadi A and Tesema L (2019) Privatisation of immigration detention facilities. Lancet 393(10188): 2299.

Saadi A, De Trinidad Young M-E, Patler C, et al. (2020) Understanding US Immigration Detention. Health and Human Rights 22(1): 187-197.

Sakoda RT and Simes JT (2020) Solitary Confinement and the U.S. Prison Boom. Criminal Justice Policy Review. DOI: 10.1177/0887403419895315.

El Sayed SA, Morris RG, DeShay RA, et al. (2020) Comparing the Rates of Misconduct Between Private and Public Prisons in Texas: Crime \& Delinquency 66(9): 1217-1241.

Schept J (2013) 'A lockdown facility ... with the feel of a small, private college': Liberal politics, jail expansion, and the carceral habitus. Theoretical Criminology 17(1): 71-88.

Schlanger M (2013) Prison Segregation: Symposium Introduction and Preliminary Data on Racial Disparities Introduction. Michigan Journal of Race and Law 18(2): 241-250.

Schoenfeld H (2010) Mass Incarceration and the Paradox of Prison Conditions Litigation. Law \& Society Review 44(3-4): 731-768.

Schwellenback N, Steinle M, Hawkins K, et al. (2019) Isolated: ICE Confines Some Detainees with Mental Illness in Solitary for Months. Project on Government Oversight, 14 August. Available at: https://perma.cc/3Z8Y-8NZV (accessed 27 September 2019).

Shapiro DM (2019) Solitary Confinement in the Young Republic. Harvard Law Review 133(2): $542-598$.

Spivak AL and Sharp SF (2008) Inmate Recidivism as a Measure of Private Prison Performance. Crime \& Delinquency 54(3): 482-508.

Stumpf J (2006) The The Crimmigration Crisis: Immigrants, Crime, and Sovereign Power. American University Law Review 56(2): 367-420. 
Tasca M and Turanovic J (2018) Examining Race and Gender Disparities in Restrictive Housing Placements. W.E.B. Du Bois Program of Research on Race and Crime 252062. Washington, DC, USA: National Institute of Justice. Available at: https://perma.cc/58NQ-4AL5.

TRAC (2013) Legal Noncitizens Receive Longest ICE Detention. Syracuse, NY. Available at: https://perma.cc/3JRS-9X5J.

TRAC (2020) Decline in ICE Detainees with Criminal Records Could Shape Agency's Response to COVID-19 Pandemic. Syracuse, NY. Available at: https://perma.cc/4PN4-AXQS.

UN News (2011) Solitary Confinement Should Be Banned in Most Cases, UN Expert Says. 18 October. Available at: https://perma.cc/EY83-4LA3.

United Nations Standard Minimum Rules for the Treatment of Prisoners (2016) A/RES/70/175. Available at: https://undocs.org/A/RES/70/175.

Unlock the Box (2020) Solitary Confinement is Never the Answer. Available at: https://perma.cc/ZZ6N-862C.

Urbina I and Rentz C (2013) Immigrants Held in Solitary Confinement Cells, Often for Weeks. The New York Times, 23 March. Available at: https://perma.cc/W8AF-ATVH.

U.S. Immigration and Customs Enforcement (ICE) (2013) Review of the Use of Segregation for ICE Detainees, Memo 11065.1. Available at: https://perma.cc/8GHX-VL8V (accessed 27 September 2019).

van der Woude MAH, van der Leun JP and Nijland J-AA (2014) Crimmigration in the Netherlands. Law \& Social Inquiry 39(3): 560-579.

Williams B, Li A, Ahalt C, et al. (2019) The Cardiovascular Health Burdens of Solitary Confinement. Journal of General Internal Medicine 34(10): 1977-1980.

Woodman S, Saleh M, Rappleye H, et al. (2019) Solitary Voices: Thousands of Immigrants Suffer in Solitary Confinement in ICE Detention. The Intercept, 20 May. Available at: https://perma.cc/Y2QJ-A2SS.

\section{Biographical Notes}

Konrad Franco is a Sociology $\mathrm{PhD}$ student at the University of California, Davis. His research interests broadly pertain to the sociology of law and punishment along with quantitative methods. He studies jails, prisons, and immigration detention centers using administrative data.

Caitlin Patler is an Assistant Professor of Sociology at the University of California, Davis, and an Executive Committee Member of the UC Davis Global Migration Center. Her research addresses the origins and reproduction of inequality in the U.S. through an examination of laws, 
legal statuses, and law enforcement institutions as drivers of socioeconomic and health disparities.

Keramet Reiter is an Associate Professor in the Department of Criminology, Law \& Society and at the School of Law at the University of California, Irvine. She is the author of 23/7 (Yale University Press, 2016) and Mass Incarceration (Oxford University Press, 2017), and her research focuses on prison conditions, laws, and policies. 


\section{Tables}

Table 1. Summary Statistics for Key Variables with Comparison between the General Detained Population and Solitary Confinement Population

\begin{tabular}{|c|c|c|c|c|}
\hline & \multicolumn{2}{|c|}{$\underline{\text { Solitary Population }}$} & \multicolumn{2}{|c|}{ General Detained Population } \\
\hline & Frequency & Percentage/Mean & Frequency & Percentage/Mean \\
\hline Male $(1=$ yes $)$ & 5,094 & 95.63 & 282,364 & 79.42 \\
\hline Attorney of Record ( $1=$ yes $)$ & 559 & 12.53 & - & $14^{\mathrm{a}}$ \\
\hline Serious Medical Issue $(1=$ yes $)$ & 74 & 1.43 & - & - \\
\hline Mental Illness $(1=$ yes $)$ & 1,083 & 20.70 & - & $15^{\mathrm{b}}$ \\
\hline \multicolumn{5}{|l|}{ Region of Origin $(1=y e s)$ : } \\
\hline Africa & 659 & 12.37 & 5,084 & 1.43 \\
\hline Asia & 304 & 5.71 & 10,092 & 2.84 \\
\hline Caribbean & 659 & 12.37 & 7,878 & 2.21 \\
\hline Central America & 1,428 & 26.81 & 166,163 & 46.72 \\
\hline Europe & 170 & 3.19 & 3,419 & 0.96 \\
\hline Mexico & 1,739 & 32.65 & 151,455 & 42.58 \\
\hline Middle East & 156 & 2.93 & 1,593 & 0.45 \\
\hline North America & 21 & 0.39 & 479 & 0.13 \\
\hline Oceania & 27 & 0.51 & 337 & 0.09 \\
\hline South America & 164 & 3.08 & 9,169 & 2.58 \\
\hline Average Facility Daily Population (ADP) & & 799.12 & & 316.87 \\
\hline Share of Facility ADP Criminal & & 60.69 & & 44.62 \\
\hline Private Facility Operator & & 66.19 & & 68.76 \\
\hline Observations & 5,327 & & 355,678 & \\
\hline
\end{tabular}

Notes:

Solitary population data come from the ICIJ.

General detention population data come from TRAC, except where indicated.

Data about the full general detention population come from FY 2015, except where indicated.

"-_" denotes no available data.

ADP data averaged from FY 2015 to FY 2018.

ICE classifies National Crime Information Center (NCIC) offense codes into three seriousness levels; the most serious (level 1) covers "aggravated felonies," level 2 offenses cover other felonies, while level 3

offenses are misdemeanors. The share of facility ADP that is criminal is the percent of the ADP with either a level 1, 2, or 3 offense.

${ }^{\mathrm{a}}$ Eagly and Shafer (2015) ${ }^{\mathrm{b}}$ Mehta (2010) 
Table 2. Mixed Effect 2-Level Logit Regression Predicting Solitary Confinement Without a Disciplinary Infraction

\begin{tabular}{|c|c|c|}
\hline & (1) & (2) \\
\hline \multirow[t]{2}{*}{ Male } & -0.106 & -0.102 \\
\hline & $(0.177)$ & $(0.178)$ \\
\hline \multirow[t]{2}{*}{ Yes-Attorney of Record } & $0.202^{+}$ & $0.206^{+}$ \\
\hline & $(0.111)$ & $(0.112)$ \\
\hline \multirow[t]{2}{*}{ Yes-Medical Issues } & $0.813^{* *}$ & $0.806^{* *}$ \\
\hline & $(0.272)$ & $(0.273)$ \\
\hline \multirow{2}{*}{ Yes-Mental Illness } & $1.109^{* *}$ & $1.205^{* *}$ \\
\hline & $(0.100)$ & $(0.222)$ \\
\hline \multirow{3}{*}{$\begin{array}{l}\text { Region of Origin (Ref: sample grand mean): } \\
\quad \text { Africa }\end{array}$} & & \\
\hline & $-0.384^{* *}$ & $-0.384^{* *}$ \\
\hline & $\begin{array}{c}(0.129) \\
0.091\end{array}$ & $\begin{array}{c}(0.130) \\
0.088\end{array}$ \\
\hline Asia & $(0.157)$ & $(0.157)$ \\
\hline \multirow[t]{2}{*}{ Caribbean } & -0.168 & -0.169 \\
\hline & $(0.135)$ & $(0.135)$ \\
\hline \multirow[t]{2}{*}{ Central America } & -0.015 & -0.014 \\
\hline & $(0.112)$ & $(0.112)$ \\
\hline \multirow[t]{2}{*}{ Europe } & 0.131 & 0.129 \\
\hline & $(0.190)$ & (0.190) \\
\hline \multirow[t]{2}{*}{ Mexico } & 0.031 & 0.031 \\
\hline & $(0.109)$ & (0.109) \\
\hline \multirow[t]{2}{*}{ Middle East } & 0.095 & 0.096 \\
\hline & $(0.201)$ & $(0.201)$ \\
\hline \multirow[t]{2}{*}{ Oceania } & -0.217 & -0.214 \\
\hline & $(0.539)$ & $(0.539)$ \\
\hline \multirow[t]{2}{*}{ South America } & -0.176 & -0.174 \\
\hline & $(0.195)$ & (0.195) \\
\hline \multirow{2}{*}{ Average Facility ADP FY15-FY18 } & -0.001 & -0.001 \\
\hline & $(0.000)$ & $(0.000)$ \\
\hline \multirow{2}{*}{ Share of Facility ADP Criminal FY15-FY18 } & -0.006 & -0.006 \\
\hline & $(0.010)$ & $(0.010)$ \\
\hline \multirow[t]{2}{*}{ Private Facility } & $0.949^{*}$ & $0.963^{*}$ \\
\hline & $(0.469)$ & $(0.470)$ \\
\hline \multirow[t]{2}{*}{ Yes-Mental Illness x Private Facility } & & -0.120 \\
\hline & & $(0.247)$ \\
\hline \multirow[t]{2}{*}{ Intercept } & 0.194 & 0.179 \\
\hline & (0.698) & $(0.700)$ \\
\hline \multirow[t]{2}{*}{ SD of Random Facility Intercepts } & $0.547^{* *}$ & $0.549^{* *}$ \\
\hline & $(0.150)$ & $(0.151)$ \\
\hline AOR Fixed Effects & Yes & Yes \\
\hline Observations & 4346 & 4346 \\
\hline BIC & 5294.992 & 5303.133 \\
\hline AIC & 5033.535 & 5035.299 \\
\hline Log-Likelihood & -2475.767 & -2475.649 \\
\hline$x^{2}$ & 266.581 & 266.147 \\
\hline
\end{tabular}

Log odds coefficients.

Standard errors in parentheses.

${ }^{+} p<0.10,{ }^{*} p<0.05,{ }^{* *} p<0.01$ 
Table 3. Mixed Effect 2-Level Negative Binomial Regression Predicting Number of Days in Solitary Confinement

\begin{tabular}{|c|c|c|}
\hline & (1) & (2) \\
\hline \multirow[t]{2}{*}{ Confinement without Infraction } & $0.685^{* *}$ & $0.605^{* *}$ \\
\hline & $(0.023)$ & $(0.042)$ \\
\hline \multirow[t]{2}{*}{ Male } & $0.176^{* *}$ & $0.175^{* *}$ \\
\hline & $(0.049)$ & $(0.049)$ \\
\hline \multirow[t]{2}{*}{ Yes-Attorney of Record } & 0.037 & 0.037 \\
\hline & $(0.032)$ & $(0.032)$ \\
\hline \multirow[t]{2}{*}{ Yes-Medical Issues } & $-0.515^{* *}$ & $-0.507^{* *}$ \\
\hline & $(0.082)$ & $(0.082)$ \\
\hline \multirow[t]{2}{*}{ Yes-Mental Illness } & $0.317^{* *}$ & $0.314^{* *}$ \\
\hline & $(0.029)$ & $(0.029)$ \\
\hline \multicolumn{3}{|l|}{ Region of Origin (Ref: sample grand mean): } \\
\hline \multirow[t]{2}{*}{ Africa } & -0.017 & -0.018 \\
\hline & $(0.036)$ & $(0.036)$ \\
\hline \multirow[t]{2}{*}{ Asia } & -0.065 & -0.061 \\
\hline & $(0.044)$ & $(0.044)$ \\
\hline \multirow{2}{*}{ Caribbean } & -0.052 & -0.053 \\
\hline & $(0.037)$ & $(0.037)$ \\
\hline \multirow[t]{2}{*}{ Central America } & $-0.064^{*}$ & $-0.064^{*}$ \\
\hline & $(0.030)$ & $(0.030)$ \\
\hline \multirow[t]{2}{*}{ Europe } & -0.008 & -0.010 \\
\hline & $(0.055)$ & $(0.055)$ \\
\hline \multirow[t]{2}{*}{ Mexico } & $-0.062^{*}$ & $-0.063^{*}$ \\
\hline & $(0.029)$ & $(0.029)$ \\
\hline \multirow[t]{2}{*}{ Middle East } & $0.116^{*}$ & $0.117^{*}$ \\
\hline & $(0.057)$ & $(0.057)$ \\
\hline \multirow[t]{2}{*}{ Oceania } & 0.077 & 0.071 \\
\hline & $(0.133)$ & $(0.133)$ \\
\hline \multirow[t]{2}{*}{ South America } & -0.066 & -0.062 \\
\hline & $(0.056)$ & $(0.056)$ \\
\hline \multirow[t]{2}{*}{ Average Facility ADP FY15-FY18 } & $0.000^{+}$ & $0.000^{+}$ \\
\hline & $(0.000)$ & $(0.000)$ \\
\hline \multirow[t]{2}{*}{ Share of Facility ADP Criminal FY15-FY18 } & $-0.004^{+}$ & $-0.004^{+}$ \\
\hline & $(0.002)$ & $(0.002)$ \\
\hline \multirow[t]{2}{*}{ Private } & $-0.155^{+}$ & $-0.197^{*}$ \\
\hline & $(0.083)$ & $(0.085)$ \\
\hline \multirow[t]{2}{*}{ Confinement without Infraction x Private Facility } & & $0.112^{*}$ \\
\hline & & $(0.049)$ \\
\hline \multirow[t]{2}{*}{ Intercept } & $3.387^{* *}$ & $3.407^{* *}$ \\
\hline & $(0.152)$ & $(0.154)$ \\
\hline \multirow[t]{2}{*}{ SD of Random Facility Intercepts } & $0.008^{+}$ & $0.008^{+}$ \\
\hline & $(0.004)$ & $(0.005)$ \\
\hline AOR Fixed Effects & Yes & Yes \\
\hline Observations & 4,346 & 4,346 \\
\hline $\mathrm{BIC}$ & 39767.846 & 39771.154 \\
\hline AIC & 39493.634 & 39490.566 \\
\hline Log-Likelihood & -19703.817 & -19701.283 \\
\hline$x^{2}$ & 1507.242 & 1509.050 \\
\hline
\end{tabular}




\section{Figures}

Figure 1. Distribution of Time Spent in Solitary Confinement

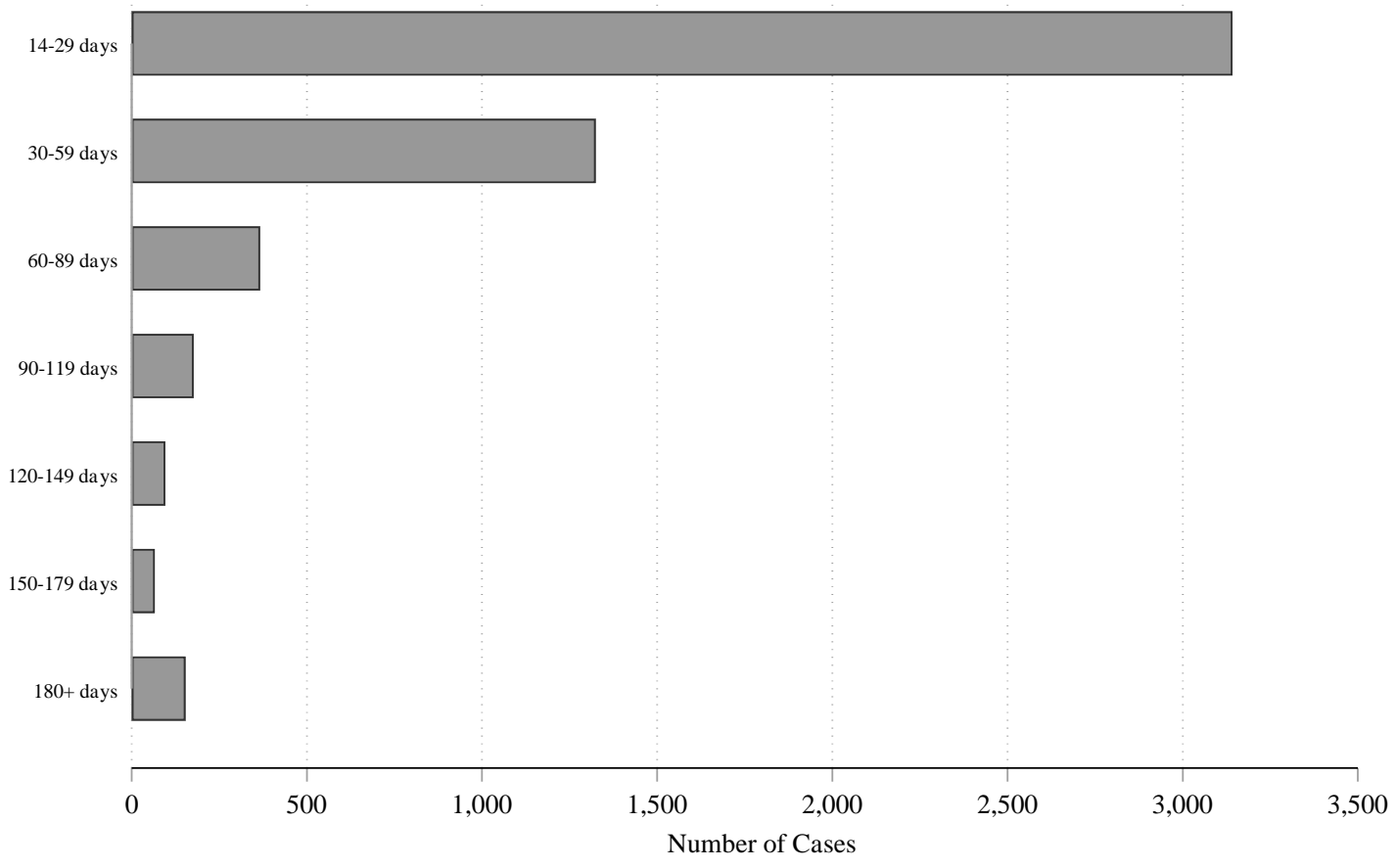


Figure 2. Distribution of Select Placement Reasons Across 25 of the Largest Detention Facilities

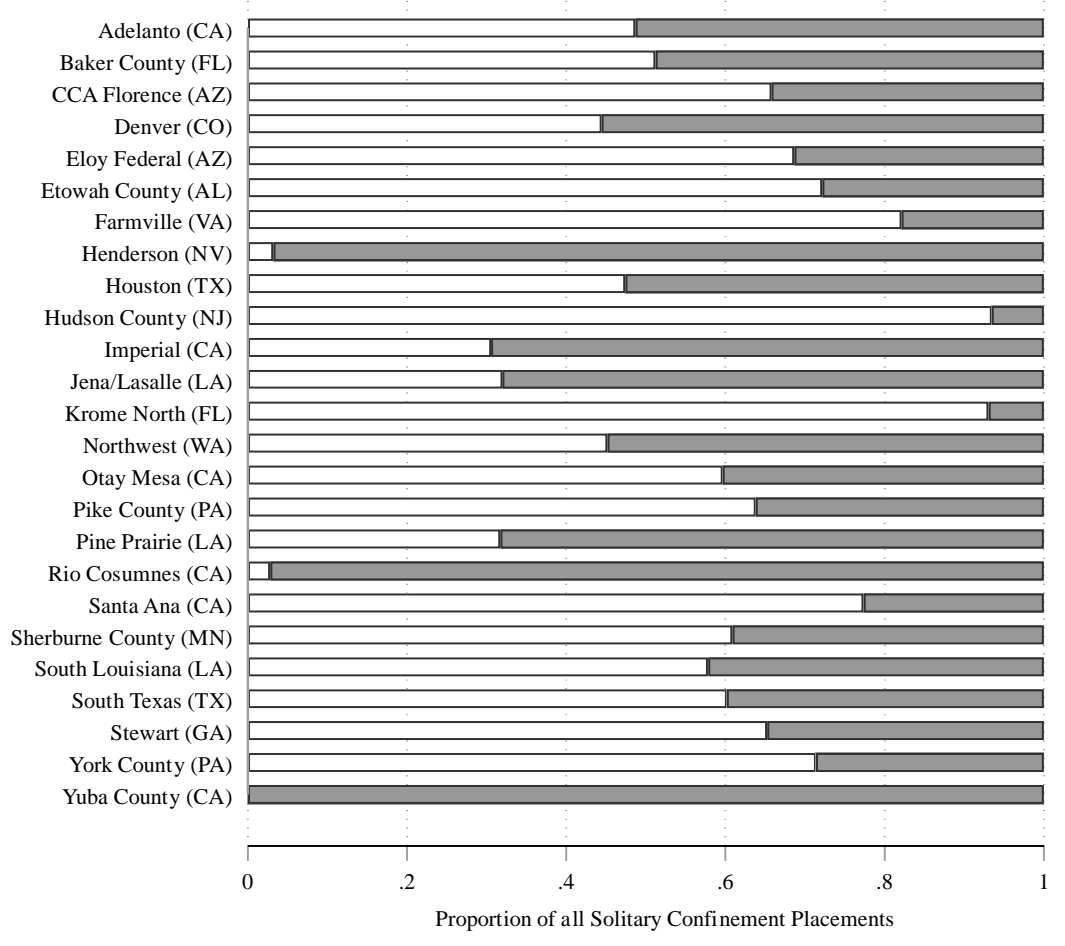

Note: Figure limited to 25 facilities with highest average daily populations (ADP)
Solitary Confinement with Infraction ( Solitary Confinement without Infraction 
Figure 3. Average Marginal Effects (AMEs) of Independent Variables on the Predicted Probability of Solitary Confinement without Disciplinary Infraction

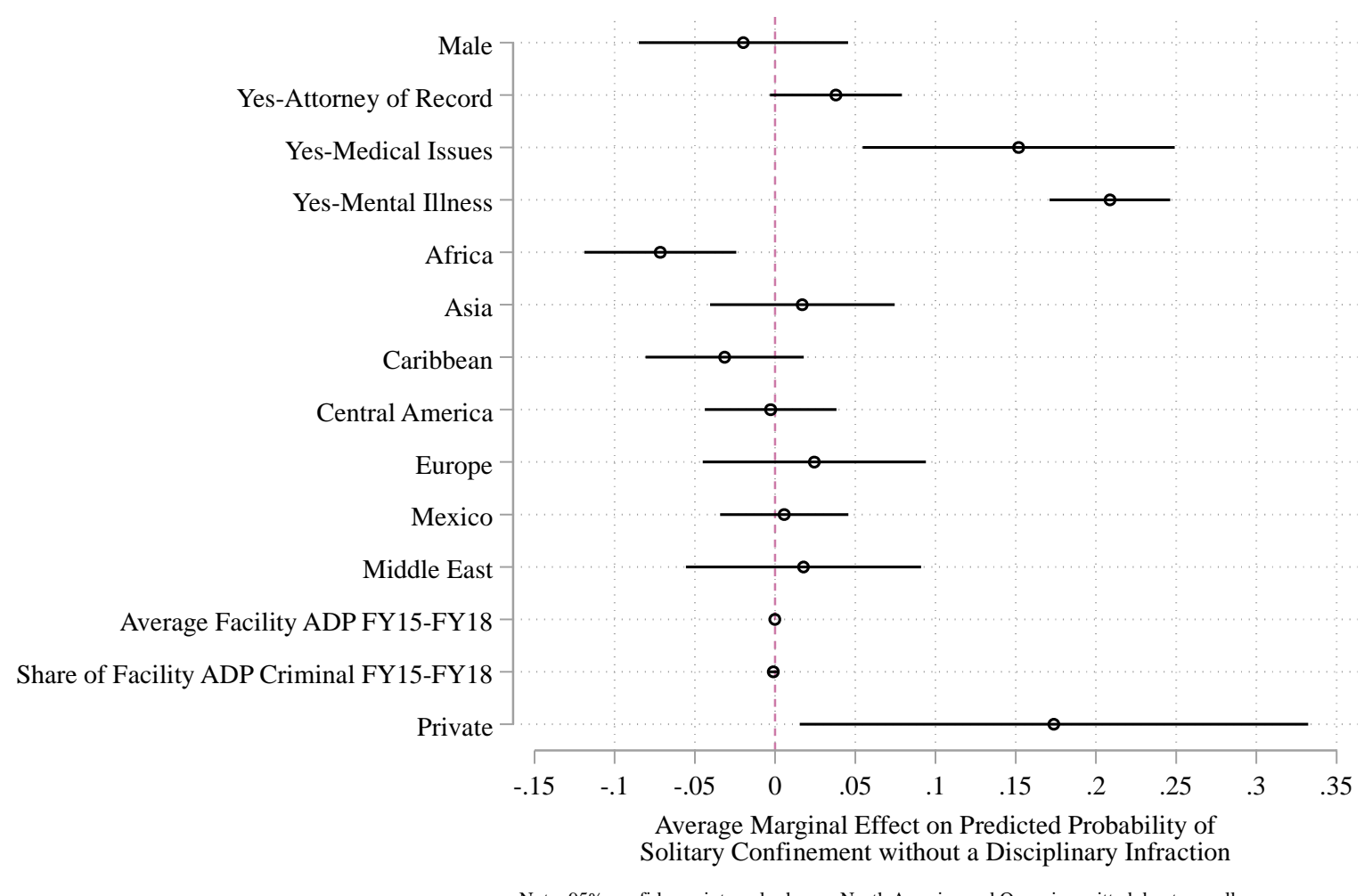

Note: $95 \%$ confidence intervals shown. North America and Oceania omitted due to small n. 
Figure 4. Average Marginal Effects (AMEs) of Independent Variables on the Predicted Number of Days Spent in Solitary Confinement

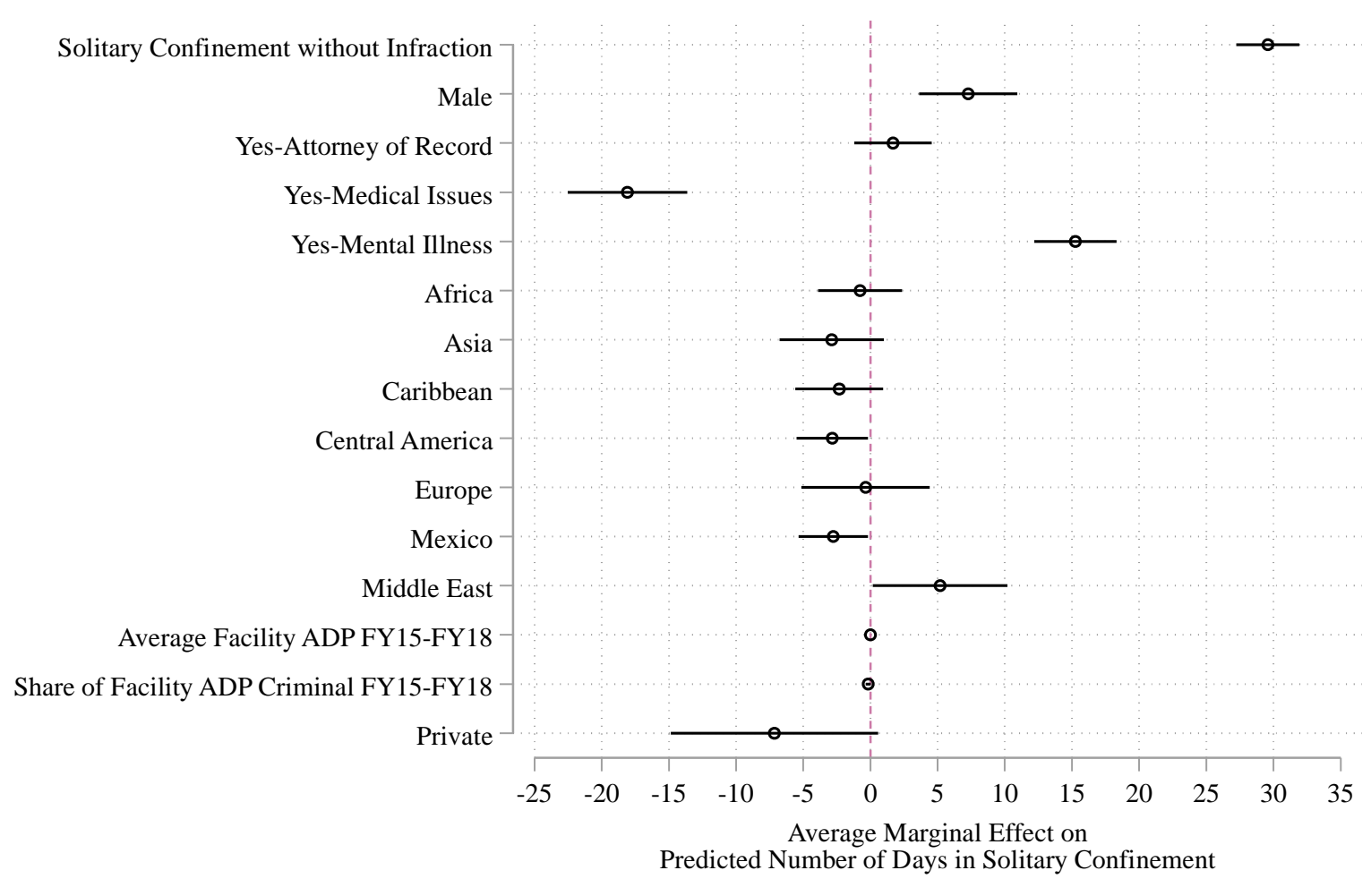

Note: $95 \%$ confidence intervals shown. North America and Oceania omitted due to small $\mathrm{n}$. 


\section{Appendices}

Appendix 1. Coding Scheme for Placement Reason Variable

\begin{tabular}{|c|c|c|c|}
\hline ICE Provided Reason & Frequency & Percent & $\begin{array}{l}\text { Solitary } \\
\text { Confinement } \\
\text { without } \\
\text { Infraction } \\
\end{array}$ \\
\hline Disciplinary & 2,776 & 52.11 & 0 \\
\hline Pending Investigation of Disciplinary Violation & 59 & 1.11 & 0 \\
\hline Facility Security Threat: Due to Seriousness of Criminal Conviction & 17 & 0.32 & 1 \\
\hline Facility Security Threat: Gang Member Status (Not Protective Custody) & 105 & 1.97 & 1 \\
\hline Facility Security Threat: Other & 138 & 2.59 & 1 \\
\hline Facility Security Threat: Violent or Disruptive Behavior & 399 & 7.49 & 1 \\
\hline Hunger Strike & 13 & 0.24 & 1 \\
\hline Medical: Detox/Withdrawal Observation & 1 & 0.02 & 1 \\
\hline Medical: Disabled or Infirm & 3 & 0.06 & 1 \\
\hline Medical: Observation & 30 & 0.56 & 1 \\
\hline Medical: Other & 55 & 1.03 & 1 \\
\hline Medical: Other Infectious Disease & 39 & 0.73 & 1 \\
\hline Medical: Segregation Unit & 2 & 0.04 & 1 \\
\hline Medical: Tuberculosis & 16 & 0.30 & 1 \\
\hline Mental Illness & 154 & 2.89 & 1 \\
\hline Mental Illness: Observation & 1 & 0.02 & 1 \\
\hline Other & 54 & 1.01 & 1 \\
\hline Protective Custody: Criminal Offense (b)(7)(e) & 151 & 2.83 & 1 \\
\hline Protective Custody: Gang Status (Protective Custody Only) & 204 & 3.83 & 1 \\
\hline Protective Custody: Lesbian, Gay, Bisexual, Transgender (LGBT) & 28 & 0.53 & 1 \\
\hline Protective Custody: Other Detainee Safety & 1,051 & 19.73 & 1 \\
\hline Protective Custody: Special Vulnerability Other & 11 & 0.21 & 1 \\
\hline Protective Custody: Victim of Sexual Assault & 4 & 0.08 & 1 \\
\hline Suicide Risk Placement & 16 & 0.30 & 1 \\
\hline
\end{tabular}


Appendix 2. Average Marginal Effects (AMEs) of Individual ICE AORs on the Predicted Probability of Solitary Confinement without Disciplinary Infraction and the Predicted Number of Days in Solitary Confinement
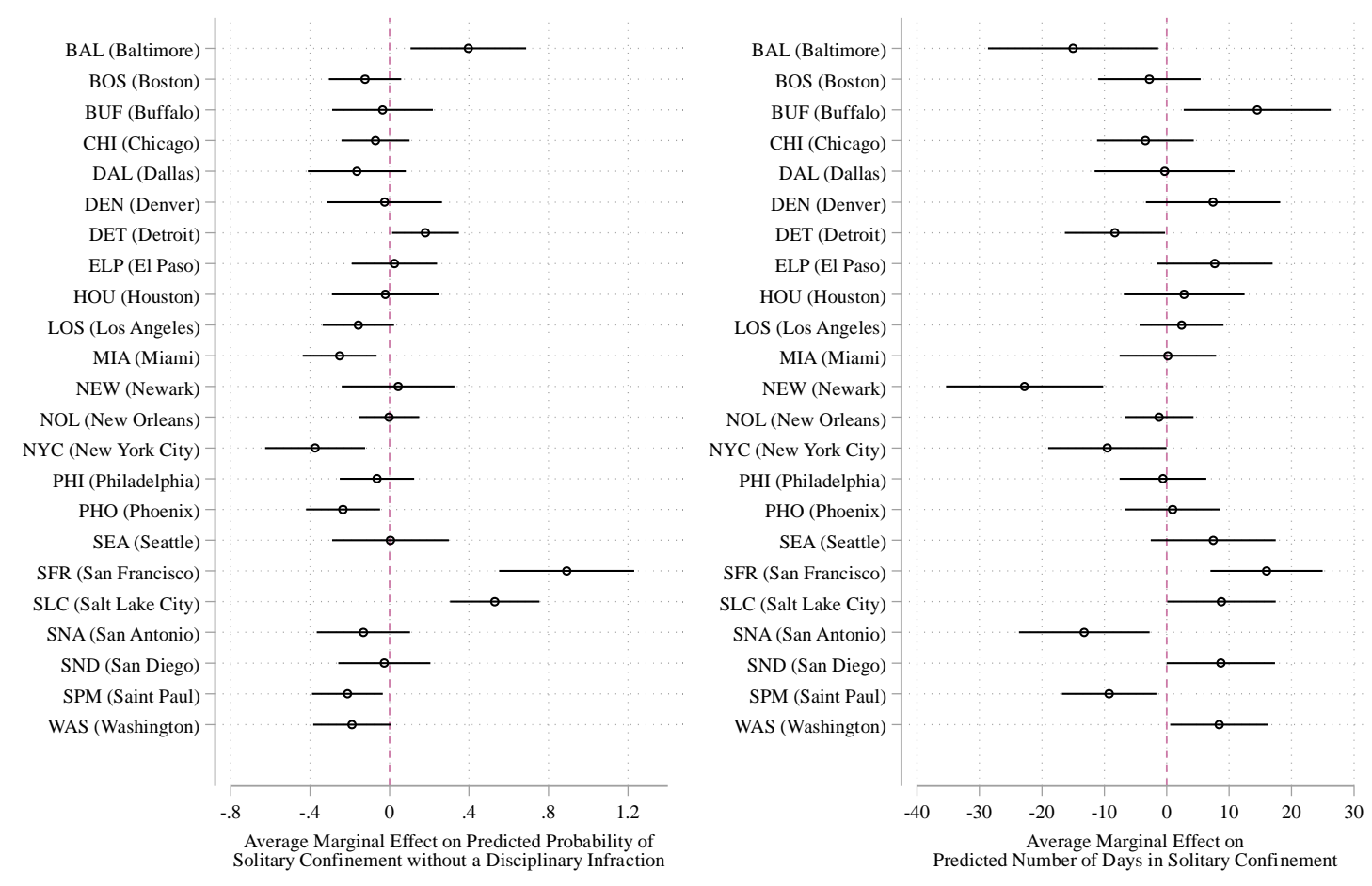

Note: $95 \%$ confidence intervals shown. Deviation effect coding. Atlanta AOR excluded. 